\title{
KESKUSTELUYHTEYTTÄ RAKENTAMASSA?
}

PEKKA KALLI ja ANITA MALINEN (toim.) (2005). Konstruktivismi ja realismi. Aikuiskasvatuksen 45. vuosikirja. Kansanvalistusseura ja Aikuiskasvatuksen tutkimusseura.

$\mathrm{P}$ aljosta puheesta huolimatta monien tuntuu edelleen olevan hankalaa päästä perille siitä, mitä kaikkea konstruktivismi on tai ei ole. Ainakin osa oppimisteoreetikoista voi syyttää myös itseään. Tarinan voisi ehkä rekonstruoida viittaamalla siihen, miten viimeistään postmodernismi-debattien kautta yhteiskuntateoriassa ja tieteen sosiologiassa yleistynyt sosiaalinen konstruktionismi ja tietoteoreettinen radikaali konstruktivismi nousivat pinnalle myös muilla ihmisja yhteiskuntatieteen kentillä. Niinpä muutamat oppimisteoreettiset konstruktivistit etenkin Yhdysvalloissa halusivat osoittaa olevansa kunnon konstruktivisteja flirttailemalla myös näiden muodikkaampien virtausten kanssa. Mikään valtavirta tämä ei ole ollut, toisin kuin esimerkiksi Tapio Puolimatka näyttää ajattelevan.

Eri tieteenaloilla on samojen vuosikymmenten kuluessa ryhdytty käyttämään 'rakentamisen' tai 'rakentumisen' metaforaa monenmoisia ilmiötä kuvaamassa. Kasvatustieteissä käsitteellistä sotkua on hämmentänyt pikemmin kuin selventänyt oppimisteoreettiseen konstruktivismiin viime vuosina suunnattu filosofisviritteinen kritiikki.

Suomalaisen debatin käynnistäneessä Opetuksen teoria -kirjassaan Puolimatka sitoo konstruktivismin muodot toisiinsa hauskalla retorisella tekniikalla. Hän toteaa itse, että useimmat [kirjassa] kuvatut konstruktivismin muunnelmat ovat loogisesti riippumattomia toisistaan, "vaikka niitä usein käsitelläänkin ikään kuin ne välttämättä liittyisivät toisiinsa” (Opetuksen teoria, 45). Mutta missä niitä näin käsitellään? Puolimatka ei mainitse lähteitä väitteensä tueksi, vaikka niputtaa yhteen hengästyttävän määrän konstruktivismin ilmentymiä psykologiasta teologiaan. Juuri hän itse ottaa kritiikkinsä lähtökohdaksi 'konstruktivismi' -käsitteen lukuisien ja eri tieteistä periytyvien käyttöjen niputtamisen.

Tämän jälkeen puhe konstruktivismista ja realismista johdonmukaisina metakäsitteinä on pesiytynyt suomalaiseen kasvatustieteeseen. Sellaisina niitä taulukoi myös Kalli kokoelman johdannossa. Yhteenvetoa kannattaa tehdä, mutta eri mieltä voi kuitenkin olla vaatimuksesta, jonka mukaan oppimisen teoriassa ontologiset, tieto- ja arvoteoreettiset sekä teologiset ulottuvuudet on otettava kokonaisuutena (13). Heti perään Kalli itsekin epämääräistää vaatimuksensa: "On pyrittävä johdonmukaiseen realismiin tai konstruktivismiin, tai yritettävä yhdistää eri näkökulmia toisiinsa.” (13) Kaikki mahdollisuudet jätetään avoimiksi. Niihin voisi lisätä vielä sen, että on mahdollista kieltäytyä realismikonstruktivismi-kielipelistä ja pärjätä silti hyvin kasvatustieteellisen tutkimuksen parissa.

Tutkimuksessa ja opetuksessa on totta kai tärkeää sel- ventää tiedollisia ja moraalisia taustaoletuksiaan. Realismin ja konstruktivismin yleiskäsitteet ovat kuitenkin aivan liian karkeita välineitä tällaiselle taustatyölle yksittäisissä tapauksissa, tutkijan pohtiessa oman tutkimuskohteensa luonnetta ja lähtökohtiaan. Toisekseen keskustelu on vaarassa synnyttää kuvitelman, ettei empiiristä tutkimusta voi edes aloittaa, ellei ole ratkaissut kuluneen kahden ja puolentuhannen vuoden tärkeimpiä filosofisia kiistakysymyksiä. Kannattaa siis miettiä, miksi ylipäätään moinen vastakkainasettelu on haluttu luoda ja mikä sen motivoi. Käsittääkseni taustalla on ennen kaikkea moraalinen huoli, joten palaan siihen myöhemmin.

Artikkelit etenevät oppimisteorioista (Päivi Tynjälä, Hannu Heikkinen ja Rauno Huttunen), tieteenfilosofian (Tapio Puolimatka), toiminnan teorian (Katariina Holma ja Tiina Kontinen), ohjaustyön (Jussi Onnismaa) ja kasvatusetiikan (Mia Salo) kautta Max Schelerin arvo-objektivismin esittelyyn (Ulla Solasaari). Kirjan runko muodostuu Aikuiskasvatuksen tutkijatapaamisessa Jyväskylässä 2003 pidetyistä esitelmistä, vaikkei tätä mainitakaan.

Useimmat artikkelit ovat mukiinmenevää luettavaa. En ryhdy yksitellen kertaamaan niiden sisältöä. Sanottakoon, ettei yksikään niistä puolla vahvaa tietoteoreettista konstruktivismia, mutta useimmat arvostavat konstruktivismia oppimisteoriana. Itseäni kiinnostaa pääasiassa kriitikoiden panos, koska konstruktivismin muotoja sopii kri- 
tikoida ja koska kriittinen ääni on ollut keskustelun primus motor.

\section{KESKUSTELUA}

\section{PUOLIMATKAN KANSSA}

Vaikka kokoelman konstruktivismi-kriittiset tekstit eroavat muuten toisistaan suuresti, niitä yhdistää teistinen realismi: kasvatuksen tulee perustua kristilliselle uskolle (Salo) ja transsendentille arvorealismille (Solasaari), jotta sillä olisi moraalinen oikeutus, ja tieteessä vain supranaturalismi (ja tarkemmin ottaen monoteismi) voi pelastaa ihmistiedon ja todellisuuden yhteyden (Puolimatka).

Puolimatkan artikkeli alkaa suorilla väitelauseilla: ”Jokaisella ihmisellä on oma tutkimusohjelmansa sekä arkielämässä että tieteessä siinä mielessä, että jokainen meistä nojautuu joihinkin tiedon lähteisiin ja pitää niitä luotettavina. Tällaisia tiedon lähteitä ovat havainto, muisti, järjellinen päättely, rationaalinen ja eettinen intuitio ja uskonnollinen kokemus. Tällä hetkellä tieteessä vallitseva naturalistinen tutkimusohjelma hyväksyy näistä tiedon lähteistä havainnon, muistin ja järjellisen päättelyn ja katsoo tieteellisen menetelmän rakentuvan pelkästään niiden varaan.” (49)

En tiedä, miksi lukijan pitäisi hyväksyä oletus "tutkimusohjelmien” kaikenkattavuudesta, naturalismin hallitsevuudesta esimerkiksi kasvatustieteessä tai Puolimatkan tässä konstruoima luettelo tiedon lähteistä. Niitä ei pyritä perustelemaan, mutta niillä luodaan otollinen alkuasetelma.

Tuskin kukaan moderni tieteenfilosofi perustaa tieteellistä tiedonhankintaa koskevaa näkemystään sinänsä filosofian alkeisopinnoista muistuttavaan luetteloon "tiedon lähteistä". Tieteellisen tutkimuksen piirteitä ja väitteiden oikeuttamisen tapoja pyritään sen sijaan rajaamaan käytännöissä, joita eivät määritä yksilöiden "tiedon lähteet”, vaan tieteellisen toiminnan sosiaaliset säännöt. Tällaisten luetteloita on monenlaisia, mutta tyypillisesti mainitaan esimerkiksi intersubjektiivisuus, kommunikoitavuus, tarkistettavuus tai toistettavuus, falsifioitavuus ja niin edelleen.

Uskonnolliset kokemukset eivät toteuta edellä lueteltuja tieteelliselle tutkimukselle asetettuja odotuksia - eikä niiden tarvitsekaan. Koko erottelun, ja tieteellisen tutkimuksen ja tiedonmuodon sosiaalisen luonteen, Puolimatka hämärtää väittäessään, että naturalistit ahdasmielisesti sulkevat jo ennakolta pois tieteen piiristä uskonnolliseksi kokemukseksi kutsutun "tiedon lähteen".

Lisäksi Puolimatkan teksteille on tässä kuten muuallakin tyypillistä raju yleistäminen, esimerkiksi puhe sekä tieteestä että todellisuudesta yksikkömuodossa ja monoliittisina. Tällöin jäävät erittelemättä luonnontieteellisen ja yhteiskuntatieteellisen tutkimuksen ominaispiirteet sekä todellisuuden erilaiset ilmiötasot materiaalisista esineistä kulttuurisiin merkityksiin. Tätä kannattaa verrata Onnismaan valaisevaan tekstiin, jossa eritellään konstruktivismin merkitystä nimenomaan yhden ihmistieteellisen tutkimusalan ja käytännön (ohjaustyön) näkökulmasta.

Kuten koko konstruktivismikeskustelussa, ongelmien yhtenä alkusyynä on se, ettei Puolimatka muodosta kritiikkinsä kohteista kuvaa näiden omien tekstien ja itsemäärittelyn kautta, vaan ottamalla annettuna toisen kriitikon kuvaukset niistä. Tässä tapauksessa suurin osa artikkelista pohjautuu Michael Rean teokseen. Artikkelin pääkohteena on naturalistinen tieteenfilosofia, mutta tekstistä ei löydy nykyaikaisen filosofisen naturalismin edustajia, lukuun ottamatta lyhyttä lainausta Quinelta. Tämä muistuttaa siitä, miten vähän Opetuksen teoria -teoksesta löytyy sen paremmin realistien kuin konstruktivistienkaan omaa ääntä.

Artikkelissaan Puolimatka jatkaa Opetuksen teoriassa aloitettua filosofista tarkastelua. Hän toistaa Rean argumentaation, jonka mukaan realistinen ajattelu on mielekästä vain supranaturalistisen (yliluonnollisen sisällyttävän) tutkimusohjelman puitteissa.

Varioiden Quinen tunnetuksi tekemää väitettä, jonka mukaan jokainen teoria voidaan pelastaa lisäämällä siihen uusia poikkeuslausekkeita, voi samaan tapaan minkä tahansa argumentaation viedä läpi, kunhan rakentaa sille otolliset puitteet ja kuljettaa sen riittävän monen tukipremissin kautta. Lukijan pitäisi hyväksyä koko joukko kirjoittajan asettamia rajauksia ja olettamuksia eli pelata peliä juuri Puolimatkan haluamalla tavalla, jotta argumentaatio tuntuisi toimivan. Kovin eleganttia se ei ole ja aukkojakin jää.

Argumentaatiojaksojen keskinäinen yhteys vahvistetaan tavallisesti retorisilla toteamuksilla ("kuten havaitaan”, "siten”), olipa niiden välillä seuraussuhdetta tai ei. Esimerkiksi: "Pragmaattisten totuusteorioiden mukaan on olemassa vält- 
tämätön vastaavuus sen välillä, mikä on totta, ja sen, mitä täydellisen järkevä yhteisö uskoo sellaisissa olosuhteissa, joissa sillä on kaikki tieto käytettävissään. Tämä väite puolestaan johtaa hyvin teismin kaltaiseen väitteeseen, jonka mukaan ensinnäkin on olemassa välttämättä olemassa oleva rationaalinen yhteisö ja toiseksi on välttämättä olemassa kaikkitietävä yhteisö.” (65) Virkkeiden välillä ei tietenkään ole loogista seuraantoa, jossa toinen johtaisi toiseen. Puolimatka saa argumentin pintatasolla näyttämään siltä käyttämällä välttämättömyyden modaalitermiä, mutta muuttaen sen paikkaa ja merkitystä.

Argumentaationsa Puolimatka pukee monisanaiseen retoriikkaan, joka monesti pikemmin vaikeuttaa kuin helpottaa punaisen langan seuraamista. Argumentaation tueksi käytetään ad hoc -asetelmia, vastustajien näkemysten karrikointia, aiheesta käytyjen keskustelujen yksinkertaistamista ja hypoteettisten argumentaatioiden kautta etenemistä. Näiden monografioistaankin tuttujen argumentaatiotekniikoiden ongelmia Puolimatka ei ole voinut olla tiedostamatta, koska niistä on jo aikaa sitten huomautettu myös kansainvälisessä palautteessa. $^{1}$

\section{SOLASAARI JA SCHELER}

Konstruktivismin kriitikoista Ulla Solasaaren teksti erottuu selkeydellään. Tunnustusta on annettava myös Suomessa vähän tunnetun filosofin ja filosofisen perinteen tunnetuksi tekemisestä. Hiukan toivomisen varaa jättää se, että Solasaaren Max Scheler-tulkinnat edustavat klassikoiden hyväksyvään parafraasiin pysähtyvää filoso- fian tutkimuksen tapaa. Tekstistä ei löydy kohtaa, jossa Scheler kontekstoitaisiin tekstikriittisesti tai asetettaisiin keskusteluun kriitikoidensa kanssa.

Problematisoinnille löytyisi paljon tilaa. Olennainen nivelkohta liittyy muun muassa siihen, miten Scheler kiinnittää toisiinsa fenomenologisen lähtökohtansa, jossa maailma on aina ihmisen tietoisuuden konstituoivan toiminnan tulosta, ja objektivistisen moraaliteoriansa, jossa arvotodellisuuden on oltava yksilölliset konstituutiot ylittävästi kaikille yhteinen. Solasaari katsoo, ettei ongelmaa ole, koska Schelerin mukaan "ihmisen tunteiden, intentioiden, järjen ja tahdon rakenne vastaa maailmassa olevien asioiden ja asiayhteyksien arvorakennetta” (161). Miksi näin on, sitä ei problematisoida, vaikka kysymys oli Schelerille itselleen hyvin vaikea ja johti lopulta jonkinlaiseen etäisyydenottoon aiemmista näkemyksistä. Mitä hankalimman ongelman ratkaisu tulee kuin kaupan hyllyltä, tai taivaasta, kuten Deus ex machina.

\section{ILMOITUKSENOMAINEN ARVOTOTUUS KASVATUSPERUSTANA?}

Moraalirelativismin ja -realismin kiistan perkaaminen on aina ansiokasta työtä, joskin siihen kaipaisi enemmän nyanssien tajua, kuin tässä keskustelussa esiintyy. Kriitikoiden sanoma on matkan varrella muuttunut kärjekkäämmäksi. Mia Salon teksti on tästä esimerkki. Siinä hän esittää, kuten väitöskirjassaan, että oikeanlaisen kasvatuksen avaimena on siirtyminen ihmisen itsetekemän moraalin kuvitelmasta ja siitä seuraavasta väärästä syyllisyydestä per- soonallisen Jumalan asettaman moraalijärjestyksen ja oikean syyllisyyden vastaanottajaksi. Oikealla syyllisyydellä Salo tarkoittaa käsittääkseni teologiassa tutummin perisynniksi kutsuttua asiaa. Kasvattajan on nöyrryttävä tunnistamaan ja tunnustamaan oma syntisyytensä, jotta hänestä olisi kasvattajaksi. Sekä moraalisen että tiedollisen kasvatuksen perustaksi on otettava selkeä auktoriteettien hierarkia (Jumala - ilmoitus - opettaja/vanhempi oppilas/lapsi). Kuten Salon mukaan ihminen erehtyy "kieltäessään” yllämainitun auktoriteettirakenteen totuuden, on Puolimatkan mielestä ongelmana se, miten ihminen "torjuu tietoisuuden Jumalasta välttääkseen kosmista auktoriteettia.” (78)

Ilmoituksenomainen arvototuus nähdään tässä tapauksessa myös kasvatustieteissä relevantiksi lähtökohdaksi. Ajattelutavan vahvistuminen on tietysti yksi tunnettu reaktio epävarmuuden lisääntymiseen yhteiskunnassa, kuten maailman tapahtumista voi huomata. En silti tiedä esimerkkiä kulttuuriyhteisöstä, jossa moraaliseen objektivismiin tukeutuvan fundamentalismin vahvistuminen olisi johtanut eettisen harkinnan ja keskustelun kehittymiseen. On hyviä syitä pikemminkin epäillä, että oikeassa olemisen moraaliseen varmuuteen perustuvilla kasvatusjärjestelmillä on saatu aikaan enemmän tuhoa kuin moraalisesta epävarmuudesta seuraavalla varovaisuudella tai jopa täydellä välinpitämättömyydellä.

Kaipuu yhtenäisen moraalijärjestyksen perään on vahvaa, mutta voi etsiä onnen avaimia väärästä suunnasta. Saattaa näyttää siltä, että esimerkiksi 
suomalaista elämää jäsensi jaettu moraalihorisontti vielä neljäkymmentä vuotta sitten, ja tällä oli suotuisa vaikutus kasvatukseenkin. Sopinee epäillä: oliko yhteiskunta sittenkään aivan homogeeninen, tulivatko kulttuuristen ylärakenteiden moraalikoodit osaksi ihmisten arkea, perustuivatko ohikiitävissä arjen hetkissä tehdyt kasvatusratkaisut sisäistettyihin periaatteisiin, tai oliko yhtenäinen julkismoraali siunauksellista kasvatuksen kannalta?

\section{MORAALIKONSTRUKTIVISMI JA MORAALIREALISMI}

Paljon on muuttunut, mutta en etsisi kasvatuksen kannalta tärkeimpiä muutoksia hengen sfääreistä ja moraalin julkilausumista. Kiinnostavampaa on arjen mikrorakenteiden muutos sosiaalisissa verkostoissa, perhe- ja ihmissuhteissa, tavoissa, harrastuksissa, työurissa, mediassa, ajanvietteissä ja yksinkertaisesti yhdessä olemisen käytännöissä. Voi väittää, että turvallisuus, myötätunto, luottamus, toisten kunnioitus ja muut pienissä arjen askareissa ilmenevät mikromoraaliset piirteet ovat merkityksellisempiä kuin se, millaiseen moraalikoodistoon kulloinkin on tietoisesti sitouduttu tai oltu sitoutumatta. Laajojen käsitteellisten maisemien tähystäminen on filosofien työsarkaa, mutta tässä kohdin olisi mentävä sosiologien ja sosiaalipsykologien oppiin.

Moraalikasvatuksen kohdalla kritiikissä on hyvää keskustelun herättely ja ylläpito. Hallaa keskustelulle tekee käsitteistön hämmentäminen. Salo asettaa moraalirealismin vastakohdaksi moraalikonstruktivismin, jonka mukaan "moraalinen todellisuus ymmärretään ihmisen konstruoimaksi ja aktiivisesti rakentamaksi kokonaisuudeksi” (130). Näyttää kuitenkin selvältä sosiaaliselta faktalta, että maailma on täynnä ihmisten erilaisia tapoja rakentaa moraalinen järjestyksensä. Moraalikonstruktivismi ei täten ole mikään kiistakysymys vaan selviö, eikä sen sovittamisessa yhteen moraalirealismin kanssa (tieteellisestä realismista puhumattakaan) ole ylipääsemätöntä ristiriitaa, jos näin halutaan. Moraalirealismin varsinaisena vastakohtana voi pitää moraalirelativismia, jonka mukaan toisistaan poikkeavien moraalikäsitysten ("konstruktioiden") taustalla ei ole yhtä totuutta oikeasta moraalista.

On vaikea nähdä, miksi relativismin kritiikki on pitänyt pukea konstruktivismikritiikin asuun. Ainakaan se ei selvennä asiaa. Huoli moraalirelativismista leimaa joka tapauksessa kritiikkiä niin vahvasti, että lukijaa helpottaa, jos kriitikoita lukiessaan toisinaan vaihtaa sanan 'konstruktivismi' tilalle sanan 'relativismi'. Itse asiassa myös Puolimatkan Opetuksen teorian muutamat käsittämättömimmät jaksot tulevat tämän lukutavan avulla lähes ymmärrettäviksi.

\section{VASTAKKAINASETTELUN HEDELMÄLLISYYS?}

Tuntuu siltä, ettei konstruktivismi-realismi -keskustelu ole juuri tarjonnut sitä kasvatusfilosofian laadullista kehittymistä, jota kasvatusalan arviointiraporteissa jo 80-luvun puolella toivottiin. Sen sijasta yleisen tieteenfilosofian puolella kirjoitetut perusteokset toimivat edelleen käypänä johdantona peruskysymyksiin myös kasvatuksen tutkimuksessa. Lähemmäs tutkimuskäytäntöjä tullen saman voi sanoa tutkimuskohteiden luonnetta ja menetelmien taustaoletuksia avaavista teoksista, joita löytyy sekä menetelmäkirjallisuudesta että kasvatuksen tieteenalan omien perusteiden historiallisista tai analyyttisistä esittelyistä. Niitä pitäisin konstruktivismi-realismi -köydenvetoa varteenotettavampana kasvatustieteen tieteenfilosofiana.

Varustin pääotsikon kysymysmerkillä, koska on epäselvää, rakentuuko keskusteluyhteyttä kantojen välille. Selvimmin sellainen on olemassa Katariina Holman ja Tiina Kontisen oivaltavassa artikkelissa, Kallin johdannossa, Päivi Tynjälän, Hannu L.T. Heikkisen ja Rauno Huttusen sekä Jussi Onnismaan teksteissä. Artikkelien aiheet ja lähestymistavat ovat kuitenkin niin kaukana toisistaan, ettei todellista keskustelua synny. Ehkä se kertoo siitä, etteivät nämä puitteet ole ylipäätään keskustelun kannalta hedelmälliset.

\section{Tuukka Tomperi}

\section{VIITE}

1. Katso esimerkiksi R. N. Curren Democracy and the Foundations of Morality, Philosophy of Education Yearbook 1996; D. C. Phillips, Two Essays of Tapio Puolimatka, Philosophy of Education Yearbook 1999. (Molemmat osoitteessa http:// www.ed.uiuc.edu/EPS/PESYearbook/). 